\title{
A note on the distribution of Balanophora polyandra Griff. (Balanophoraceae) in and around Neora Valley National Park, West Bengal, India
}

\author{
Sutapa Rai ${ }^{1}$, Kuntal Narayan Chaudhuri ${ }^{1}$ and Shuvadeep Majumdar ${ }^{2}$ \\ ${ }^{1}$ Department of Botany, Vivekananda College, Kolkata 700063, West Bengal, India \\ ${ }^{2}$ Department of Botany, Parimal Mitra Smriti Mahavidyalaya, Jalpaiguri 735221, West Bengal, India \\ ${ }^{2}$ Corresponding Author: shuvadeep.majumdar@gmail.com
}

[Received 10.08.2020; Revised \& accepted 25.12.2020; Published 31.12.2020]

\begin{abstract}
Balanophora polyandra Griff. of Balanophoraceae is a root holoparasitic plant, is recorded from in and around the Neora Valley National Park in the Kalimpong district of West Bengal, India. Rhopalocnemis phalloides Junghuhn, another holoparasitic plant of the same family, which was earlier reported and is very rare within this National Park also been collected. Morphology, ecology and conservation status of B. polyandra are provided here with a photo plate for its easy identification. While examining the literature, the authors feel that this taxon has been inadequately reported from this area of West Bengal by the earlier workers and hence this communication.
\end{abstract}

Key words: Balanophora polyandra, Root holoparasite, Red List, Neora Valley National Park

\section{INTRODUCTION}

The plant world shows an amazing diversity in modes of nutrition. In contrast to the autotrophic green plants, a small but significant number of heterotrophic angiosperms have adopted strikingly different approaches for obtaining all or part of their food from other plants and even from animals. They include insectivorous plants those trap small animals to supplement their $\mathrm{N}_{2}$ need. Some plants pierce their roots variously in the host tissue, forming haustoria and absorb food from the host. Again, in mycotrophic plants, some fungi enter into the tissue of host root and form a symbiotic system for survival (Heide-Jorgensen 2008).

Balanophoraceae, a small family of root holoparasites, is represented by two genera in India, viz. Balanophora J.R.Forster \& G.Forster and Rhopalocnemis Junghuhn (Hansen 1972). In India, the genus Rhopalocnemis is represented by a single species, viz. $R$. phalloides Junghuhn (Balakrishnan 2012; Rai \& Das 2013; Krishna et al. 2016), whereas Balanophora is represented by seven species and three varieties, viz. B. abbreviata Blume, B. dioica R.Br. ex Royle, B. fungosa J.R.Forster \& G.Forster, B. harlandii Hook.f., B. indica (Arn.) Griff., B. indica var. agastyamalayana M.B.Viswanathan et al., B. indica var. minor Eichler, B. indica var. tirunelveliensis M.B.Viswanathan et al., B. involucrata Hook.f. \& Thomson, B. polyandra Griff. (Balakrishnan 2012). In West Bengal, R. phalloides has already been reported (Rai \& Das 2013; Krishna et al. 2016) while the genus Balanophora is represented by three species, viz. B. abbreviata, B. dioica and B. polyandra (Mallick 2010; Balakrishnan 2012; Chhetri et al. 2018).

The Neora Valley National Park $\left(26^{\circ} 58^{\prime} 15^{\prime \prime} \mathrm{N}\right.$ to $27^{\circ} 42^{\prime} 00^{\prime \prime} \mathrm{N}$, and $88^{\circ} 40^{\prime} 01^{\prime \prime} \mathrm{E}$ to $88^{\circ} 48^{\prime} 49^{\prime \prime} \mathrm{E}$ ) with $88 \mathrm{~km}^{2}$ area situated on both sides of the Neora river is one of the oldest protected areas in India. Bordering Sikkim in the North and Bhutan in the Northeast, the National Park is located in the Kalimpong district of West Bengal. The altitude ranged from $180 \mathrm{~m}$ to $3,200 \mathrm{~m}$ supports a rich flora with numerous endemic species as a part of the 
198 Status of Balanophora polyandra in Neora Valley National Park
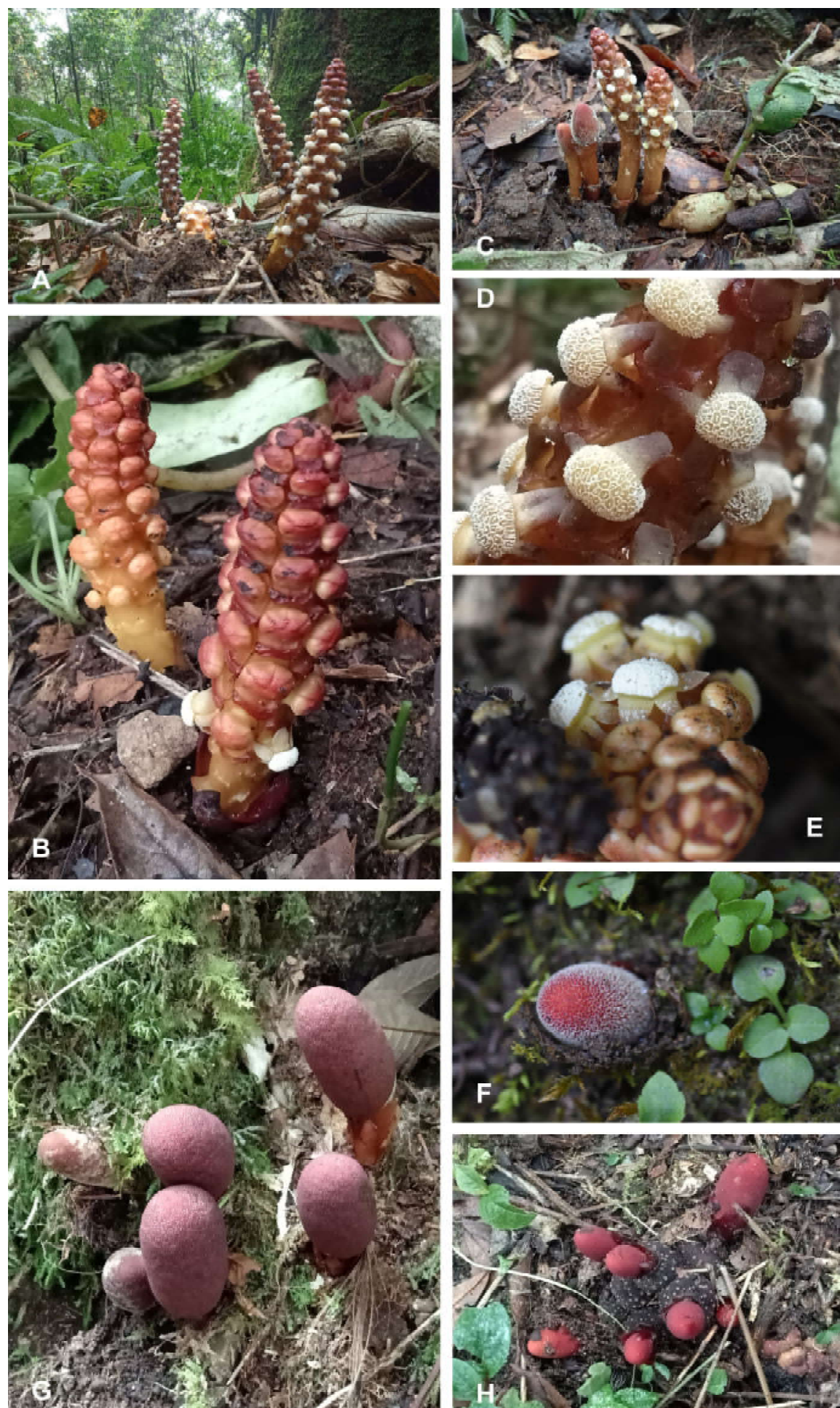

PLATE - I. Balanophora polyandra Griff. (Balanophoraceae). A \& B. Male plants growing on forest floor; C. Male and female plants growing in close vicinity; D \& E. Enlarged male flowers showing synandarium; F. A putative female plant; G \& H. Full grown female plants. 
Himalaya Biodiversity Hotspot. The difficult terrain makes this inaccessible area one of the last remains of undisturbed and unexplored wildernesses in West Bengal (Rai \& Das 2002).

\section{Balanophora polyandra in and around Neora Valley National Park:}

During intensive floristic surveys in and around the Neora Valley National Park during 2015 to 2019, Balanophora polyandra was first observed under Quercus sp. at Rishyap (27'11'12" N, $\left.88^{\circ} 65^{\prime} 26^{\prime \prime} \mathrm{E}\right)$ in November, 2015 and later on it was spotted in between Rishyap and Lava $\left(27^{\circ} 08^{\prime} 63^{\prime \prime} \mathrm{N}, 88^{\circ} 66^{\prime} 15^{\prime \prime} \mathrm{E}\right)$ in November, 2015. In October 2019, both B. polyandra and R. phalloides were spotted inside the Neora Valley National Park in many places like Bhotaykharka $\left(27^{\circ} 02^{\prime} 19.4^{\prime \prime} \mathrm{N}, 88^{\circ} 46^{\prime} 85.0^{\prime \prime} \mathrm{E}\right)$, Chilbre $\left(27^{\circ} 03^{\prime} 35.2^{\prime \prime} \mathrm{N}, 88^{\circ} 46^{\prime} 22.5^{\prime \prime} \mathrm{E}\right)$, Hillay, Malingay,

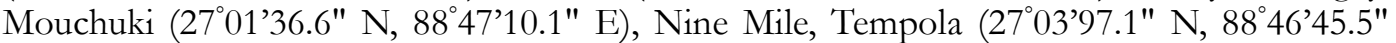


E). For identification and confirmation, the herbarium specimens housed in ASSAM, BSHC and CAL herbaria were consulted.

\section{Taxonomy}

Balanophora polyandra Griff., Proc. Linn. Soc. London 1: 220. 1844; J.D. Hooker, Fl. Brit. India 5: 238. 1886; Balakrishnan in Balakrishnan et al. (eds.), Fl. India 23: 77. 2012.

Parasitic, dioecious, tubers clustered together forming a mass; single tubers subspherical, $1-$ $3 \mathrm{~cm}$ across; branching from the base; surface granular with scattered stellate warty protuberances, 3-6 cm in diameter. Male inflorescence 5-15 cm long, 1-2 cm wide, terminal, ellipsoid with expanded flowers, racemose; pedicellate; flowers zygomorphic, numerous, spirally arranged in conspicuous vertical rows; synandarium laterally elongated, somewhat compressed subdiscoid. Female inflorescence 3-7 cm long, $1.5-3.0 \mathrm{~cm}$ wide, terminal, ellipsoid to obovate, brick red; flowers zygomorphic, numerous and minute, arranged on main axis of inflorescence.

\section{Distribution}

B. polyandra is distributed in India (Assam, Arunachal Pradesh, Manipur, Maharashtra, Nagaland, Sikkim, West Bengal); Bhutan, China, Myanmar and Nepal (Hansen 1972; Shumei \& Murata 2003; Mallick 2010; Balakrishnan 2012; Chhetri et al. 2016; O’Neill \& Rana 2016).

\section{Association}

The preferred habitat of B. polyandra as observed by the authors is in the shaded forests along the hill slopes in association with angiosperms such as Quercus lamellosa Sm. (Fagaceae), Castanopsis sp. (Fagaceae), Engelhardtia spicata Blume (Juglandaceae), Exbucklandia populnea (R.Br. ex Griff.) R.W.Br. (Hamamelidaceae), Juglans regia L. (Juglandaceae) and in bamboo groves.

\section{DISCUSSION}

These fascinating root holoparasites were encountered in numerous locations during explorations in and around the Neora Valley National Park. Balanophora polyandra appears to be quite common inside the park. At Rishyap, in 2015, the cluster was with 8-10 individuals with both male and female plants. On the trekking route between Rishyap and Lava ten more populations were spotted in November, 2015. However, in November (2016), on the same route only two populations were documented. This indicated the threat encountered by the taxon in the manipulative zone of the National Park, where the preliminary observations of the populations of the taxon had been made. The detailed survey inside the National Park in 2019 recorded two populations of B. polyandra from the Mouchuki-Bhotaykharka route, 62 from BhotaykharkaThusum Khola, 34 from Bhotaykharka-Thusum peak and 12 from Bhotaykharka-Tempola. 
A single population of R. phalloides was found on the way towards Thosum Peak from Bhotaykharka $\left(27^{\circ} 04^{\prime} 348^{\prime \prime} \mathrm{N}, 88^{\circ} 45^{\prime} 803^{\prime \prime} \mathrm{E}\right)$ at an altitude of 2,170 m. Earlier, Rai and Das (2013) reported this taxon for the first time from West Bengal collected from Neora Valley National Park. Later, Krishna et al. (2016) again reported it from Neora Valley National Park.

\section{Threat and Conservation Status}

Based on IUCN Red List criteria Chhetri et al. (2018) were of the opinion that B. polyandra is a Least Concern (LC) species both in Sikkim and throughout the Eastern Himalaya due to its wide distribution and has stable population within several protected areas. In Sikkim, the taxon has been recorded from two protected areas, viz. Khangchendzonga National Park and Pangolakha Wildlife Sanctuary (Chhetri et al. 2018). From our observations in 2015 and 2016 on the trekking route between Rishyap and Lava, it can be concluded that the species can not tolerate in the manipulated habitat. But, it appears to be quite common inside the Neora Valley National Park as there are virtually no human interventions and the fragile natural habitats are well-restored, so the taxon is still Least Concerned (LC) within the confines of the National Park, but not in the localities outside. So, only in situ conservation can save this species and, however, its populations inside such Protected Areas are appreciable.

\section{Acknowledgements}

The authors thank the Principals of Vivekananda College, Kolkata and Parimal Mitra Smriti Mahavidyalaya, Jalpaiguri for their encouragements. One of us (SM) also thank Mr. Ujjal Ghosh, IFS, Chief Conservator of Forests, Wildlife (North), Jalpaiguri and Miss Nisha Goswami, DFO, Gorumara Wildlife Division for their help in the exploration and logistic support during the stay in Neora Valley National Park. We also thank Prof. Jer-Ming Hu, National Taiwan University for confirmation of the identity of the specimen and Dr. Pieter B. Pelser, Senior Lecturer in Plant Systematics, University of Canterbury Herbarium (CANU) for providing literature.

\section{LITERATURE CITED}

Balakrishnan, N.P. 2012. Family Balanophoraceae. In: Balakrishnan, N.P. et al., (eds.). Flora of India, vol. 23:. Botanical Survey of India, Kolkata. Pp. 71 - 78

Chhetri, P.K.; O’Neill, A.R. \& Chhetri, B. 2018. Root holoparasite Balanophora polyandra Griff. (Balanophoraceae) in eastern Himalaya (Sikkim, India): distribution, range, status and threats. Journal of Threatened Taxa 10(8): 12123 - 12129. http://doi.org/10.11609/ jott.3644.10.8.12123-12129

Hansen, B. 1972. The genus Balanophora J.R. \& G. Forster. A taxonomic monograph. Dansk Botanisk Arkiv 28: 1 - 196.

Heide-Jorgensen, H.S. 2008. Parasitic flowering Plants. Brill, Leiden.

Krishna, G.; Kumar, A.; Ranjan, V. \& Goswami, N. 2016. Rhopalocnemis phalloides (Balanophoraceae): A root parasite from Neora Valley National Park, West Bengal. ENVIS Newsletter 21(2): 7.

Mallick, J.K. 2010. Neora Valley - A new short-listed World Heritage Site. Tigerpaper 37(3): $12-16$.

O’Neill, A.R. \& Rana, S.K. 2016. An ethnobotanical analysis of parasitic plants (Parijibi) in the Nepal Himalaya. Journal of Ethnobiology and Ethnomedicine 12: 14. http://doi.org/10.1186/ s13002-016-0086-y 
Rai, P.C. \& Das, A.P. 2002. Analysis of the flora of Neora Valley National Park in Darjeeling District of West Bengal, India. In: Das, A.P. (ed.) Perspectives of Plant Biodiversity. Bishen Singh Mahendra Pal Singh, Dehradun. Pp. 135-150.

Rai, P.C. \& Das, A.P. 2013. Occurrence of Rhopalocnemis phalloides Junghuhn (Balanophoraceae) in Neora Valley National Park, a new record for West Bengal, India. Pleione 7: 247 - 249.

Shumei, H. \& Murata, J. 2003. Balanophoraceae. Flora of China 5: 272 - 276. 